\title{
Sociolinguistic variation in Novgorod birchbark documents: the case of no. 907 and other letters
}

\section{Социолингвистическое варьирование в новгородских грамотах на бересте: № 907 и другие письма}

\author{
Jos Schaeken
}

Published online: 24 September 2011

(C) The Author(s) 2011. This article is published with open access at Springerlink.com

\begin{abstract}
In this paper it is argued that the variation between local and supradialectal grammatical features in birchbark letter no. 907 from Novgorod is not accidental, but sociolinguistically motivated from a communicative point of view. In addition, other birchbark documents are discussed-in particular nos. 23 and 755 from Novgorod-which may reveal similar sociolinguistic awareness on the part of the scribes.
\end{abstract}

Аннотация В статье показывается, что варьирование локальных и наддиалектных морфологических особенностей в новгородском берестяном письме № 907 носит не случайный характер, а социолингвистически мотивировано с коммуникативной точки зрения. Попутно рассматриваются и другие берестяные грамоты, в частности № 23 и № 755, обнаруживающие сходную социолингвистическую осведомленность их писцов.

\section{Introduction}

This paper is a follow-up on previous articles recently published in this journal which deal with the communicative structure of birchbark letters (Collins 2011; Gippius and Schaeken 2011; and Schaeken 2011). I will address the pragmaphilological and sociolinguistic peculiarities of the Novgorod birchbark letter no. 907 (N907, where N stands for Novgorod). In Sects. 2 and 3, the text will be glossed and translated, and its complicated contents will be discussed. In Sect. 4, I will adduce arguments in support of the hypothesis that N907 was written in two consecutive stages, each with their own communicative perspective. In these two 'writing events', the scribe consciously applied different, sociolinguistically motivated grammatical features. In the last section, other birchbark documents-in particular N23 and N755-will be discussed, which may reveal similar sociolinguistic awareness on the part of the writers.

I am greatly indebted to Daniel E. Collins, The Ohio State University, Egbert Fortuin, Leiden University, and Alexey A. Gippius, Institut slavjanovedenija RAN, for commenting on earlier drafts of this article.

J. Schaeken $(\varangle)$

Department of Slavic Languages and Cultures, Leiden University, Leiden, The Netherlands

e-mail: j.schaeken@hum.leidenuniv.nl 


\section{The text}

N907 was found in 1999 during excavations at the Trinity site (Troickij raskop, usad'ba E, kvadrat 1483), located in the medieval quarter known as People's End (Ljudin konec), on the Sophia Side of the city, south of the Kremlin. A preliminary edition of the document was published by V. L. Janin and A. A. Zaliznjak (Janin and Zaliznjak 2000, 7f.). Subsequently, the text was included in volume 11 of the Academy edition (Janin, Zaliznjak and Gippius 2004, 99-101), and, without further modifications, in the second edition of Zaliznjak's (2004) Drevnenovgorodskij dialekt (DND, 255-257).

The document $(38.5 \times 7.4 \mathrm{~cm})$ is dated stratigraphically to the end of the eleventh or the beginning of the twelfth century, while extra-stratigraphical evidence places it in the first two decades of the twelfth century (DND, 255).

Edition according to DND (255), normalized transcription and translation:

A Outer side

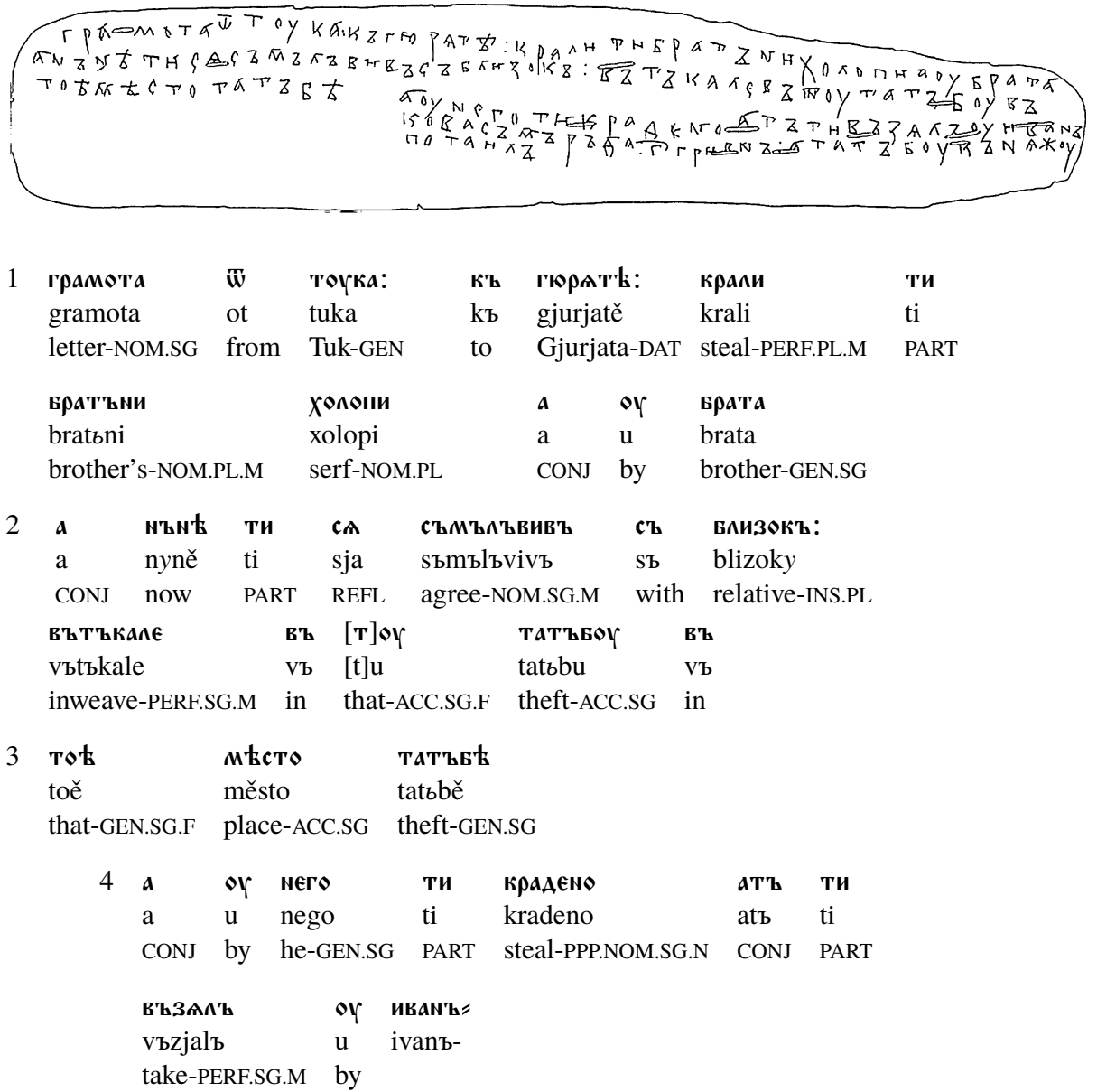




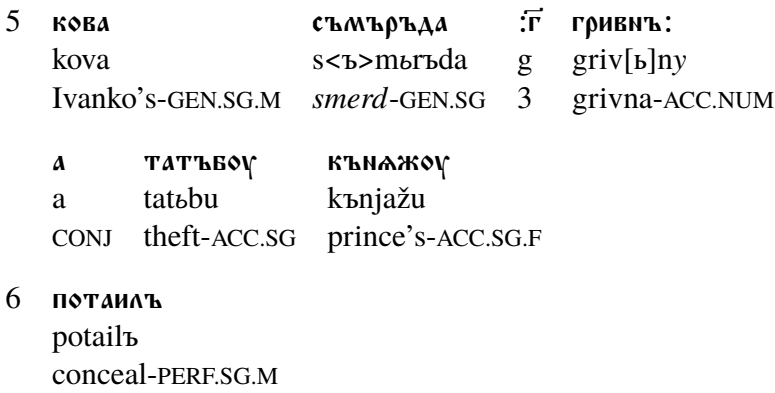

B Inner side

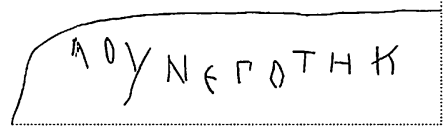

$\begin{array}{llllll}1 & \text { a } & \text { or } & \text { мего } & \text { ти } & \text { к } \\ & \text { a } & \mathrm{u} & \text { nego } & \text { ti } & \mathrm{k} \ldots \text { (i.e. kradeno) } \\ & \text { CONJ } & \text { by } & \text { he-GEN.SG } & \text { PART } & \text { (steal-PPP.NOM.SG.N) }\end{array}$

A1-3 'Letter from Tuk to Gjurjata. The brother's serfs have stolen, [they have stolen] from his brother. And now he [the landlord] has plotted with the relatives; he has shifted [everything] on this theft, instead of [telling about] that theft.'

A4-6 'From him [in his district] there has been stolen indeed, but in fact he has taken from Ivanko's smerd ${ }^{1}$ three grivnas [as hush money] and has concealed the theft of the princely property.'

B1 'From him ...'?

\section{Contents}

As noted in the edition, the text is highly condensed and difficult to interpret: “Это крайне сжатое и поэтому трудное для интерпретации послание можно понимать только как не первое звено в некотором обмене информацией” (DND, 255). According to the edition, N907 is a report of an administrative person who was sent to conduct an investigation in a criminal case which apparently involved conspiracy and bribery to conceal an earlier theft of princely property. The investigator and sender of the letter, carrying the name-or nickname (see DND, 257) — Tuk, reports to his superior, who is the addressee Gjurjata. The latter can be identified with some degree of confidence ("практически надежно", DND, 256) as the posadnik Gjurjata, who must have held the office at the time N907 was written. Ivanko, who is mentioned in A4-5, may well be the future posadnik Ivanko Pavlovič, who also figures elsewhere on birchbark (see DND, 256, 262-265, 288).

\footnotetext{
${ }^{1}$ A smerd is a peasant or artisan, who pays tribute directly to the state, not to a feudal lord (DND, 239).

${ }^{2}$ Russian translation (DND, 255): A1-3 'Грамота от Тука к Гюряте. Крали-то братнины холопы, [крали] у брата. А теперь он (хозяин дома), сговорившись с родственниками, свалил [всё] на эту кражу, вместо [того, чтобы объявить] о той краже.'-А4-6 'А у него (в его ведомстве) действительно украдено, ан ведь он взял (за свое молчание) у Иванкова смерда три гривны, а кражу княжеского имущества скрыл.'-В1 'А у него ...'.
} 
The edition provides the following reconstruction of the course of events: The main character, whose name is not mentioned (' $\mathrm{X}$ '), is an officer who supervises some 'princely' (i.e., state) property. The smerd of a certain Ivanko has stolen something from that property, and $\mathrm{X}$ knows about it. Instead of revealing the theft, $\mathrm{X}$ takes three grivnas from the smerd as hush money. ${ }^{3}$ However, the crime is discovered anyway, so the posadnik Gjurjata instructs Tuk to investigate the matter. Letter no. 907 is Tuk's report, in which he first writes an account of his findings about an earlier theft which took place in X's house: something was stolen from X's brother by his own serfs. $X$ decided to cover up the theft of the princely property-for which he was responsible-by claiming that it was part of the theft committed by his brother's serfs. Since there must have been witnesses to what actually happened, $\mathrm{X}$ had to make an arrangement with his relatives to give false testimony in his favor. In sum: "Умелый следователь Тук смог всё это распутать и посылает посаднику свой лаконичный отчет” (DND, 256).

\section{Discussion}

The first comments in the edition concern the layout of the text: "Грамота тщательно обрезана; обоим краям придана овальная форма. Текст отчетливо делится на основную часть и добавление (приписку)" (DND, 255). Indeed, the birchbark was carefully trimmed, apparently before text A was written down; A1 is indented whereas A2-3 starts more to the left of the birchbark, and the last letter of A4 (и in иванъ|кова) seems to be squeezed in. The layout of A also suggests that A4-6 is an addendum to the main text A1-3. It is entirely clear that both parts, together with B1, are written by the same hand.

Furthermore, it is stated in the edition: “Закончив (словом татъбъ) основную часть, автор вначале перешел на оборот листа; но, написав а оу него ти к, передумал и вернулся на лицевую сторону. Здесь он поместил приписку правее и ниже основной части письма" (DND, 255). Again, this seems logical; the writer initially began to compose the addendum on the other side of the birchbark, jotted down some letters (B1), but then changed his mind and continued below the main message on the outer side (A4-6). A similar procedure is also found in N69 and N723, although in both cases we are dealing with the incipit of the main text ( $\mathbf{w}$ тьр and + поки[a], respectively), not with an additional note.

However, what is strange in the case of N907 is that there was more than enough space below the main message to write the postscript in the first place, so that there was no need to start it on the other side. Moreover, N907 is unusual in the way that the writer composed the main message on the outer side of the birchbark, which is not the default side for writing (see DND, 17). Apparently, the quality of the inner side was not good enough to write on: "Возможно, ему не понравилось, что оборот листа слишком черный и на нем плохо видны буквы” (DND, 255). In this respect, N907 can be compared with N867, the only birchbark that seems to have writing only on the outer side, where the inner side had been scorched: "Береста почернела (от близости огня)" (DND, 324). Other examples of addenda (pripiska, dobavlenie) in the same hand as the main messages are written, according to DND, either immediately below the main text (N136, N831, N854), or on the other side,

\footnotetext{
${ }^{3}$ A. A. Gippius (personal communication) has suggested that it is not necessary to assume bribery in this case; it is also possible that $\mathrm{X}$, who must have had administrative authority as a supervisor of the property, simply took the three grivnas from Ivanko's smerd as a penalty for the offense he committed and then concealed the crime as well as the fine which he collected.
} 
apparently because of lack of space on the side on which the main text was written (N724, N809, Smolensk 12). One wonders why the writer of N907 on the one hand composed his main text deliberately on the (non-default) outer side of the birchbark, but on the other began writing the addendum on the inner side, being aware of (a) its poor quality and (b) the available space below the main text on the outer side.

In my opinion, a logical scenario which explains these questions about the layout and composition of N907 is to assume two different writing events. The first writing event resulted in A1-3. At some later moment, when the writer had already forgotten why he had not used the inner side and had also forgotten about the available space below the main message, he began to compose his addendum on the default side of the birchbark (B1). Immediately thereafter, he realized his mistake and started over again on the outer side, under the first message (A4-6).

There is an additional argument which points to the assumption that the addendum reflects a writing event that is different from the main text. Although N907 is mostly homogeneous orthographically and linguistically, two salient morphological inconsistencies can be observed. First, we encounter the local Novgorodian NOM.SG.M ending $-e$ in въът'ъкалє (A2), but the supradialectal ending $-ъ$ in възамиъ (A4) and потаикъ (A6). Second, татъвь (A3) shows the local GEN.SG.F/NOM.ACC.PL.F ending - $\check{e}$, whereas in гривмъ (A5) the final jer-letter represents the supradialectal ending $-y$ (DND, 256). ${ }^{4}$

The use of both local and supradialectal grammatical variants in N907 was already mentioned in the preliminary edition and the Academy edition: "Словоформы вътъкале и Р. ед. татъбъ выдают новгородское происхождение автора; но сам он старался писать по общерусской норме [...]” (Janin and Zaliznjak 2000, 8; Janin, Zaliznjak and Gippius 2004, 100). In DND, the grammatical peculiarities of N907 are characterized as 'dialectal morphology with inconsistent correction' (“Морфология диалектная с непоследовательной коррекцией”, 256). This phenomenon can be observed in a number of birchbark documents and reflects a particular sociolinguistic attitude of the writer towards his text: basically, the Novgorodian scribe tries to conform to a more widespread and prestigious linguistic form of his text by avoiding the most prominent dialectal feature, i.e. the NOM.SG.M ending - $e$. However, other local features, which are perceptually less salient because of a less transparent contrast with their supradialectal variants, are retained. For the cases where this procedure was executed systematically, ${ }^{5} \mathrm{DND}$ uses the qualification 'dialectal morphology with correction’: “Такую морфологию можно обозначить как ди а ле к тн ую с коррекци ей: пишущий проявляет свою установку на более престижную форму языка в том, что он устраняет самую яркую диалектную черту-окончание И. ед. - $е$; но все остальные диалектизмы сохраняются" (101). In other cases, where the scribe is less skilled or careful and isolated instances of the NOM.SG.M ending $-e$ still occur, the same phenomenon is further specified as 'inconsistent'. According to DND, this is what characterizes the grammar of N907 and a number of other birchbark letters. ${ }^{6}$

\footnotetext{
${ }^{4}$ In Sect. 2, гривмъ (griv[b]ny) is glossed as ACC.NUM, which refers to the special grammatical status of the NOM-ACC endings $-y$ and $-\check{e}$ after the numerals 3 and 4 (cf. DND, 99, on the evaluation of the instance гривнъ in N907, and, in the glossary, 728, s.v. гривна, the category "B. [счетн.]").

5 “[...] в частности, грамоты № 831, 849, 879, 819, 531, 213, 377, 761, 138, блок Онцифора и ряд других” (DND, 101); cf. also N417 (“Морфология близка к типу с коррекцией”, DND, 545).

6“[...] в частности, грамоты № 907, 736б, 550, 806, 142, 689, блок 215, блок Григория” (DND, 101); cf. also the postscript on the inner side of N724 ("Постскриптум-морфология диалектная с непоследовательной коррекцией", DND, 352) as well as N366, in which the author "явно стремился соблюсти нормы официального языка" (DND, 613f.).
} 
It has not yet been noticed that the variation in the grammatical endings in N907 is not inconsistent at all when we take their textual distribution into account. We find, on the one

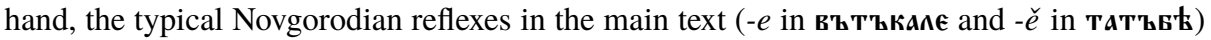
and, on the other hand, their supradialectal counterparts in the addendum (-ъ іn въззАли $\mathbf{z}$ and потаикъ, and $-y$ in гривкъ). In my opinion, the distribution is no coincidence and supports the hypothesis that N907 was composed in two separate stages. In the first one, the writer had no problem with using prominent local grammatical endings, whereas in the second stage he chose to avoid precisely these Novgorodian features.

A scenario which presupposes a temporal interval between A1-3 and A4-6 begs the question of when the addendum was composed. At what point in the course of the investigations did the sender of N907, who also might have been the writer, jot down B1 and then A4-6? The most plausible hypothesis is that this event took place after Tuk got further information at Ivanko's place, from Ivanko's intimates or perhaps from Ivanko himself; it is Ivanko's smerd who is identified in the addendum as the person who gave $\mathrm{X}$ three grivnas, which is crucial evidence in the complicated intrigue that is reported in two consecutive stages in N907.

The second question which can be raised is why the writer of the letter used local linguistic features in the main text and their supradialectal counterparts in the addendum. The very fact that he is obviously aware of applying different sociolinguistic registers under different circumstances - in this case, different writing events - has a parallel in another birchbark letter, namely N724 (probably written between 1161 and 1167; see DND, 350-354), where supradialectal features in the main text on the outer side of the birchbark alternate with their local counterparts in the postscript on the inner side. Note that the distribution of the two morphological features in N907, which are discussed above, is the same as in N724. In the case of N724, the use of different sociolinguistic registers has already been observed and commented on in DND (352):
Можно думать, что текст на обороте был написан не сразу вслед за основным текстом, а в какой-то другой момент. Если при написании основного текста ав- тор был настроен на 'правильное' письмо, т.е. на соблюдение книжной графики и наддиалектной морфологии, то в момент составления приписки он, очевидно, чувствовал себя более вольно.
Так или иначе, грамота № 724 оказывается уникальным свидетельством того, что в древней Руси грамотные люди (или, по крайней мере, некоторые из них) умели писать в разных манерах, т.е. были способны при надобности менять свою орфографическую и грамматическую установку. ${ }^{7}$

In my opinion, N907 is another example of clear sociolinguistic awareness on birchbark. One wonders to what extent, in the addendum, the writer of N907 wanted to reflect, by the avoidance of typical Novgorodian linguistic features, the high social status of the informant Ivanko or members of his milieu, who provided him with further evidence for his investigations.

\footnotetext{
${ }^{7}$ The generally accepted view (see DND 350 and all previous editions and articles on N724) that the whole document - outer and inner side — was written by a single hand, has recently been questioned by P. V. Petruxin (Petruxin 2009, 123-125). In his opinion, the sociolinguistic differences between both sides of the birchbark can be explained best by assuming two different writers: a professional scribe who was responsible for the main text on the outer side, and the sender of the letter, Savva, who wrote the postscript on the inner side. Since Petruxin provides only inconclusive paleographic evidence in favor of his theory, I prefer to stick to the view as given in the latest edition.
} 
Such a hypothesis is less speculative than it seems at first sight; there is another birchbark where the distribution of local and supradialectal features can be explained in a similar way, namely N142 (dated to the beginning of the fourteenth century; see DND, 536-538). As already pointed out by W. Vermeer (Vermeer 1996, 43), the writer of N142, Esif, uses the local NOM.SG.M ending $-e$ in the main text of his letter ('and I myself [came] will settle the matter with him'), but switches over to the supradialectal variant $-\varangle$ when giving a formal instruction in direct speech which the addressee is supposed to deliver ('[...] answer him like this: "As

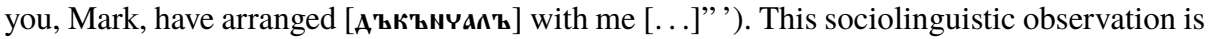
further developed in DND (537) and commented on in the following words: "наддиалектное дъкъниалъ употреблено здесь в официальном заявлении Марку, которое Есиф хочет вложить в уста адресату, тогда как, говоря от себя, Есиф употребляет диалектное cаме" (537). In the case of N907, one might argue along similar lines that the investigator, Tuk, had a different sociolinguistic mindset when reporting his finds in the addendum, voicing someone else's words, or, to put it in the words of DND, “говоря от себя".

\section{Other cases of sociolinguistic awareness on birchbark}

As noted above, N907 is not the only birchbark letter that, according to DND (101), reveals a 'dialectal morphology with inconsistent correction'. N142 is mentioned in the same list (see fn. 6); however, as we have seen in Sect. 4, its sociolinguistic composition is more subtle than that which is implied by the general qualification 'inconsistent correction'. In other cases that fall into the same category, it is not very clear what motivated the scribe to switch (back and forth) from the local NOM.SG.M ending $-e$ to the supradialectal variant $-\tau$ or vice versa. In N736b (beginning of the twelfth century), which at the beginning shows an instance of $-e$, followed by three instances of $-\varangle$, it looks as if the scribe consciously changed his mind in the course of writing his letter: "автор как бы спохватился, что он пишет слишком попросту, и далее уже употреблял наддиалектное окончание” (DND, 265). But take for instance N689 (an execution of a will written on both sides of the birchbark and dated to the second half of the fourteenth century), which contains five cases of a NOM.SG.M ending in $-e$, and six cases in $-\varangle$; in sixteen lines, the writer switches six times between both variants, apparently without any system.

Outside the category of 'dialectal morphology with inconsistent correction', there are other cases on birchbark where the NOM.SG.M ending $-e$ co-occurs with its supradialectal counterpart -ъ. In some of them, the motivation for the variation is quite obvious; the scribe principally uses the local variant except in lexemes that clearly belong to the religious or

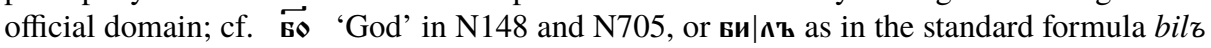
čelomb in N471. On the other hand, there are also cases that may be suspected of containing a distribution between the two variants which may be less haphazard than it seems at first sight. More particularly, I would like to draw the attention to two more recent documents, dated to the late fourteenth, perhaps early fifteenth century: N23 (DND, 647f.) and N755 (636-638).

N23 is a short letter (nine lines) of a certain Karp to his lord, Foma. In the body of the text, where Karp reports about estate management affairs, we find two instances of the supra-

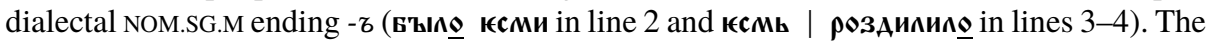
letter concludes with two short lines, for which there does not seem to be very much room at the bottom of the birchbark strip; the handwriting is a little bit smaller than the rest of the document, although it is surely the same handwriting. In these last two lines, Karp ends his letter by writing 'and Pjantelik has seen it himself'. It is hard to believe that it is pure coincidence that this concluding statement contains the local NOM.SG.M ending - $e$ (а Памтькик⺊ 


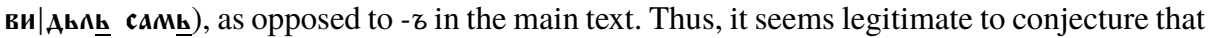
the final remark about the presence of a witness was added on second thought and written with a different sociolinguistic orientation.

In a recent article, Gippius and Schaeken $(2011,21)$ have proposed a new reading of $\mathrm{N755}$, which is an eyewitness report of an unknown writer/sender containing a question and a reply phrased in direct speech: "Oleksej asked him [i.e. Ostaška]: 'Why are you threshing without our peasants? After all, half the land and part of the crop belong to us.' [Ostaška's reply:] 'My elder, Ivan, ordered me to thresh all of your corn.' " At the beginning of the letter, when referring to himself, the writer uses the NOM.SG.M ending - $e$ in his report: пөзвan€ менє | ш̈лєкьс ви ма гүмнь 'Oleksej summoned me into the barn'. However, when quoting Ostaška's statement he uses the alternative ending $-\boldsymbol{\sigma}$ in the perfect tense form 'ordered':

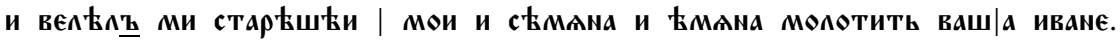

As we have seen in the previous section, exactly the same distribution can be observed in N142. In our new interpretation of N755, the quotation of Ostaška's answer continues until the end of the letter at which point the elder, Ivan, is mentioned. His name is written with the NOM.SG.M ending - $e$ : иванє. In a consistent line of reasoning, this would imply that the name is not part of the quote anymore, but comes straight from the mouth of the writer of N755, as some sort of further specification for the recipient of the report: '..."My elder ordered me to thresh all of your corn", [i.e.] Ivan'. This hypothesis might be supported by the unusual syntax of the sentence, as already observed in DND (637): "Во фразе [...] примечателен порядок слов: он отчетливо подчинен принципу 'вначале главная часть сообщения, затем уточнения'”.

\section{Conclusion}

To sum up, I have argued that the distribution of local and supradialectal features is not always random but can be an intentional reflection of the writer's sociolinguistic perceptions (and a mark of boundaries in the text). It is somehow unsatisfactory that there still remain a dozen other instances where we can merely identify both variants of the NOM.SG.M ending in one and the same text, not being able to give a plausible explanation for their distribution. For obvious reasons, in historical research the disclosure of complex sociolinguistic dynamics has its limitations.

Open Access This article is distributed under the terms of the Creative Commons Attribution Noncommercial License which permits any noncommercial use, distribution, and reproduction in any medium, provided the original author(s) and source are credited.

\section{References}

Collins, D. E. (2011). Reconstructing the pragmatics of a medieval marriage negotiation (Novgorod 955). Russian Linguistics, 35(1), 33-61.

DND: Zaliznjak, A. A. (2004). Drevnenovgorodskij dialekt. Vtoroe izdanie, pererabotannoe s učetom materiala naxodok 1995-2003 gg. Moskva.

Gippius, A. A., \& Schaeken, J. (2011). On direct speech and referential perspective in birchbark letters no. 5 from Tver' and no. 286 from Novgorod. Russian Linguistics, 35(1), 13-32.

Janin, V. L., \& Zaliznjak, A. A. (2000). Berestjanye gramoty iz novgorodskix raskopok 1999 g. Voprosy jazykoznanija, 2, 3-14.

Janin, V. L., Zaliznjak, A. A., \& Gippius, A. A. (2004). Novgorodskie gramoty na bereste (iz raskopok 19972000 gg.). Moskva. 
Petruxin, P. V. (2009). K izučeniju novgorodskoj berestjanoj gramoty no. 724. Russkij jazyk v naučnom osveščenii, 17(1), 109-126.

Schaeken, J. (2011). Don't shoot the messenger. A pragmaphilological approach to birchbark letter no. 497 from Novgorod. Russian Linguistics, 35(1), 1-11.

Vermeer, W. (1996). Historical dimensions of Novgorod inflexion. In A. A. Gippius, T. M. Nikolaeva, \& V. N. Toporov (Eds.), Rusistika. Slavistika. Indoevropeistika. Sbornik k 60-letiju Andreja Anatol'eviča Zaliznjaka (pp. 41-54). Moskva. 